\title{
Chelating Behaviour of Dihydrothieno[3,4, d] Pyridazine Derivatives with Some Lanthanide and Actinide Metals
}

\author{
NADIA AHMED ABDALLA
}

Chemistry Department, Faculty of Science, Aswan University, Aswan-81528, Egypt

nadia_201071@yahoo.com

Received 21 August 2015 / Accepted 2 September 2015

\begin{abstract}
Coordination compound formed by the interaction of Dihydrothieno[3,4-d]pyridazine with $\mathrm{La}(\mathrm{III}), \mathrm{Ce}(\mathrm{III}), \mathrm{Sm}(\mathrm{III}), \mathrm{Th}(\mathrm{IV})$ and $\mathrm{UO}_{2}$ (II) are prepared and characterized by elemental analysis, IR, ${ }^{1} \mathrm{H}$ NMR Mass spectra and thermal analysis. The analysis data indicate that the ligand acts as bidentate on chelation, thermogravimetric analysis confirm the presence of coordinates water. The IR spectra indicate that coordination takes place through the nitrogen of amino group and $\mathrm{C}=\mathrm{O}$ group of pyridazine ring. Antimicrobial activity of selected compounds against some bacterial strains was tested and confirm the antimicrobial activities of the ligand increase on coordination with the metal ion.
\end{abstract}

Keywords: Dihydrothieno Pyridazine, Complexes, IR, ${ }^{1} \mathrm{H}$ NMR, Mass Spectra, Thermal analysis, Antimicrobial activity

\section{Introduction}

Recently pyridazine and thienopyridazine compounds have been reported to possess varied biological activities such as antimicrobial ${ }^{1}$, antihypertensive ${ }^{2,3}$, anti-inflammatory ${ }^{4}$, antifungal activities ${ }^{5}$, antimalarials ${ }^{6-14}$.Pyridazinone nucleus has been extensively studied in the search for new and selective medicinal agents as drugs acting on the cardiovascular system $^{15}$. Furthermore, a number of thienopyridazines have been claimed to possess interesting biological and pharmacological activities such as, anticancer ${ }^{16}$, useful as oxidase inhibitor $^{17-18}$. Complexation of thienopyridazine with transition and rare earth metals have been studied ${ }^{19-36}$.

\section{Experimental}

All the chemicals used were of AR or BDH grade. Stock solutions $\left(1.0 \times 10^{-3} \mathrm{~mol} \mathrm{dm}^{-3}\right)$ of the azo compounds and metal salts $\mathrm{LaCl}_{3} \cdot 7 \mathrm{H}_{2} \mathrm{O}, \mathrm{Ce}\left(\mathrm{NO}_{3}\right)_{3} \cdot 6 \mathrm{H}_{2} \mathrm{O}, \mathrm{Sm}\left(\mathrm{NO}_{3}\right)_{3} \cdot 6 \mathrm{H}_{2} \mathrm{O}$ $\mathrm{Th}\left(\mathrm{NO}_{3}\right)_{4} .5 \mathrm{H}_{2} \mathrm{O}$ and $\mathrm{UO}_{2}\left(\mathrm{NO}_{3}\right)_{2} .6 \mathrm{H}_{2} \mathrm{O}$ are prepared by dissolving the accurate weight of the crystallized product in pure absolute ethanol. The thienopyridezines compound was 
prepared according to references described earlier ${ }^{28}$. The ligands were prepared by condensation of ethyl cyanoacetate with ethylarylhydrazone -3-oxo-butyrate (1a-c) in presence of ammonium acetate. These compounds(2a-c) reacted with elemental sulphur in refluxing and acatalytic amount of triethylamino were added. The reaction mixture was heated at reflux for 30 minute, the solid product (3a-c) formed was collected by filtration and crystallized from ethanol yield (89\%) yellow crystals.

The ligands used are ethyl 5-amino-3-(o-aminotoluene)-4-oxo-3,4-dihydrothieno[3,4d]pyridazine-1-carboxylate $\left(\mathrm{L}_{1}\right)$ and ethyl 5-amino-3-(4-nitrophenyl)-4-oxo-3,4-dihydrothieno[3,4-d]pyridazine-1-carboxylate (L2). In the preparation metal complexes (4a-c), the metal and the ligand were combined in 1:1metal:ligand ratio in the case of La(III), $\mathrm{Ce}(\mathrm{III}), \mathrm{Sm}(\mathrm{III}), \mathrm{Th}(\mathrm{IV})$ and $\mathrm{UO}_{2}$ (II) using required quantities of ethanol so as effect the solubility of the metal salts and ligand. The contents were refluxed on a hot water bath for $1 \mathrm{~h}$ and the solid that separated was filtered and dried over silica gel (Scheme 1). The chelates were analysed for their carbon, hydrogen and nitrogen contents. The results of analysis are given in Table 1. Conductance measurements on the complexes were made in DMF at $1 \times 10^{-3} \mathrm{~mol} \mathrm{dm}^{-3}$.

Table 1. Physical properties, analytical data, formula weight (F.W.) and molar conductance $\left(\Lambda \mathrm{ohm}^{-1} \mathrm{~cm}^{-1} \mathrm{~mol}^{-1}\right)$ of the prepared complexes

\begin{tabular}{|c|c|c|c|c|c|c|}
\hline \multirow{2}{*}{ Compound } & \multirow{2}{*}{ Molecular Formula } & \multicolumn{3}{|c|}{ Found (Calcd.) \% } & \multirow{2}{*}{$\begin{array}{l}\text { F.W. } \\
\text { Found }\end{array}$} & \multirow[b]{2}{*}{$A_{V}$} \\
\hline & & C & $\mathrm{H}$ & $\mathrm{N}$ & & \\
\hline $\begin{array}{c}\mathrm{L} 1 \\
\text { ligand }\end{array}$ & $\mathrm{C}_{16} \mathrm{H}_{16} \mathrm{~N}_{4} \mathrm{O}_{3} \mathrm{~S}$ & $55.39(55.81)$ & $5.04(4.65)$ & $15.97(16.28)$ & 344 & - \\
\hline $\begin{array}{r}\mathrm{L} 1 \\
\text { com }\end{array}$ & $\mathrm{C}_{16} \mathrm{H}_{16} \mathrm{~N}_{4} \mathrm{O}_{3} \mathrm{~S}\left(\mathrm{Cl}_{3}\right)$ La. $7 \mathrm{H}_{2} \mathrm{O}$ & $25.99(26.84)$ & $4.6(4.19)$ & $7.49(7.83)$ & 715.40 & 6.42 \\
\hline & $\mathrm{C}_{16} \mathrm{H}_{16} \mathrm{~N}_{4} \mathrm{O}_{3} \mathrm{~S}\left(\mathrm{NO}_{3}\right)_{3} \mathrm{Ce} . .6 \mathrm{H}_{2} \mathrm{O}$ & $24.42(24.67)$ & $4.19(3.60)$ & $11.51(12.59)$ & 778.12 & 6.18 \\
\hline & $\mathrm{C}_{16} \mathrm{H}_{16} \mathrm{~N}_{4} \mathrm{O}_{3} \mathrm{~S}\left(\mathrm{NO}_{3}\right)_{3} \mathrm{Sm} \cdot 6 \mathrm{H}_{2} \mathrm{O}$ & $24.50(24.35)$ & $4.55(3.55)$ & $11.60(12.43)$ & 788.40 & 19. \\
\hline $\begin{array}{l}\mathrm{L} 1-\mathrm{UO}_{2} \\
\text { complex }\end{array}$ & $\mathrm{C}_{16} \mathrm{H}_{16} \mathrm{~N}_{4} \mathrm{O}_{3} \mathrm{~S}\left(\mathrm{NO}_{3}\right)_{2} \mathrm{UO}_{2 .} 6 \mathrm{H}_{2} \mathrm{O}$ & $22.85(22.69)$ & $4.90(3.31)$ & $9.77(9.93)$ & 846.03 & 7.6 \\
\hline $\begin{array}{l}\text { L1- } \\
\text { com }\end{array}$ & $\mathrm{C}_{16} \mathrm{H}_{16} \mathrm{~N}_{4} \mathrm{O}_{3} \mathrm{~S}\left(\mathrm{NO}_{3}\right)_{4} \mathrm{Th}_{. .} 5 \mathrm{H}_{2} \mathrm{O}$ & $20.63(21.01)$ & $2.67(2.84)$ & $12.35(12$ & 914.04 & 7.0 \\
\hline $\begin{array}{c}\mathrm{L} 2 \\
\text { ligand }\end{array}$ & $\mathrm{C}_{15} \mathrm{H}_{12} \mathrm{~N}_{4} \mathrm{O}_{5} \mathrm{~S}$ & $49.96(50.00)$ & $3.01(3.33)$ & $15.40(15.55)$ & 360 & - \\
\hline $\begin{array}{l}\mathrm{L}_{2-} \mathrm{La} \\
\text { complex }\end{array}$ & $\mathrm{C}_{15} \mathrm{H}_{12} \mathrm{~N}_{4} \mathrm{O}_{5} \mathrm{~S} \mathrm{LaCl}_{3}$ & $30.52(29.73)$ & $1.96(1.98)$ & $10.20(9.25)$ & 605.41 & 12.1 \\
\hline $\begin{array}{c}\mathrm{L}_{2-} \mathrm{Ce} \\
\text { complex }\end{array}$ & $\mathrm{C}_{15} \mathrm{H}_{12} \mathrm{~N}_{4} \mathrm{O}_{5} \mathrm{~S}\left(\mathrm{NO}_{3}\right)_{3}$ Ce. $3 \mathrm{H}_{2} \mathrm{O}$ & $25.23(24.32)$ & $3.31(2.43)$ & $14.01(13.24)$ & 740.12 & 12.9 \\
\hline $\begin{array}{c}\mathrm{L}_{2-} \mathrm{Sm} \\
\text { complex }\end{array}$ & $\mathrm{C}_{15} \mathrm{H}_{12} \mathrm{~N}_{4} \mathrm{O}_{5} \mathrm{~S}\left(\mathrm{NO}_{3}\right)_{2} \mathrm{Sm} .6 \mathrm{H}_{2} \mathrm{O}$ & $24.61(24.25)$ & $2.92(3.23)$ & $10.98(11.31)$ & 742.40 & 8.68 \\
\hline $\begin{array}{l}\mathrm{L}_{2-} \mathrm{UO}_{2} \\
\text { complex }\end{array}$ & $\mathrm{C}_{15} \mathrm{H}_{12} \mathrm{~N}_{4} \mathrm{O}_{5} \mathrm{~S}\left(\mathrm{NO}_{3}\right)_{2} \mathrm{UO}_{2 .} 3 \mathrm{H}_{2} \mathrm{O}$ & $21.83(22.28)$ & $2.76(2.23)$ & $12.52(10.40)$ & 808.03 & 6.72 \\
\hline $\begin{array}{c}\mathrm{L}_{2-} \mathrm{Th} \\
\text { complex }\end{array}$ & $\mathrm{C}_{15} \mathrm{H}_{12} \mathrm{~N}_{4} \mathrm{O}_{5} \mathrm{~S}\left(\mathrm{NO}_{3}\right)_{4} \mathrm{Th}_{. .} \mathrm{H}_{2} \mathrm{O}$ & $19.65(20.98)$ & $2.30(1.83)$ & $13.88(13.05)$ & 858.03 & 9.19 \\
\hline
\end{tabular}

\section{Instrumentation}

The elemental analysis (C.H.N) were carried out by the Microanalytical Center, Cairo University. The IR (KBr) spectra were determined with Perkin-Elmer Infrared 127B spectrophotometer. 
${ }^{1} \mathrm{H}$ NMR spectra were recorded with a Bruker AMX-250 spectrometer. Mass spectra were recorded on a HPMs 6988 spectrometer. The thermographs of TGA of chelates were carried out by Cairo University; the data obtained were recorded using a Shimadzu TGA - 50H apparatus. The mass spectra were analysed by the EI technique at $80 \mathrm{eV}$, threshold output = $0.8 \mathrm{~V}$ and peak detection $=0.02 \mathrm{~V}$. Molar conductance are performed using WPA CM35 Conductivity Meter cell fitted with platinized platinum electrodes.

\section{Antimicrobial studies}

\section{Biological activity (Sensitivity tests) by Kirby-Bauer method}

Antimicrobial activity of the tested samples was determined using a modified Kirby-Bauer disc diffusion method ${ }^{37}$. Briefly, $100 \mu \mathrm{L}$ of the test bacteria/fungi were grown in $10 \mathrm{~mL}$ of fresh media until they reached a count of approximately 108 cells $/ \mathrm{mL}$ for bacteria or 105 cells $/ \mathrm{mL}$ for fung ${ }^{38}, 100 \mu \mathrm{L}$ of microbial suspension was spread onto agar plates corresponding to the broth in which they were maintained.

Isolated colonies of each organism that might he playing a pathogenic role should be selected from primary agar plates and tested for susceptibility by disc diffusion method ${ }^{39}$, results in good batch-to-batch reproducibility. Disc diffusion method for filamentous fungi tested by using approved standard method (M38-A) developed by, evaluating the susceptibilities of filamentous fungi to antifungal agents ${ }^{40}$. Disc diffusion method for yeasts developed by using approved standard method (M44-P) ${ }^{41}$.

Plates inoculated with filamentous fungi as Aspergillus flavus at $25^{\circ} \mathrm{C}$ for 48 hours; gram(+) bacteria as Staphylococcus aureus. Bacillus subtilis: gram(-) bacteria as Escherichia coli, Pseudomonas aeuroginosa they were incubated at $35-37{ }^{\circ} \mathrm{C}$ for $24-48 \mathrm{~h}$ and yeast as Candida albicans incubated at $30{ }^{\circ} \mathrm{C}$ for $24-48 \mathrm{~h}$ and, then the diameters of the inhibition zones were measured in millimeters ${ }^{37}$.

Standard discs of Ampicillin (Antibacterial agent). Amphotericin B (Antifungal agent) served as positive controls for antimicrobial activity but filter discs impregnated with $10 \mu \mathrm{l}$ of solvent (distilled water, chloroform, DMSO) were used as a negative control. The agar used is Meuller-Hinton agar that is rigorously tested for composition and $\mathrm{pH}$. Further, the depth of the agar in the plate is a factor to be considered in the disc diffusion method. This method is well documented and standard zones of inhibition have been determined for susceptible and resistant values.

Blank paper disks (Schleicher \& Sehuell, Spain) with a diameter of $8.0 \mathrm{~mm}$ were impregnated $10 \mu$ of tested concentration of the stock solutions. When, a filter paper disc impregnated with a tested chemical is placed on agar the chemical will diffuse from the disc into the agar. This diffusion will place the chemical in the agar only around the disc .The solubility of the chemical and its molecular size will determine the size of the area of chemical infiltration around the disc if an organism is placed on the agar it will not grow in the area around the disc if it is susceptible to the chemical. This area of no growth around the disc is known as a "Zone of inhibition" or "Clear zone". For the disc diffusion, the zone diameters were measured with slipping calipers of the National Committee for Clinical Laboratory standard ${ }^{42}$. Agar-based methods such as Etest and disk diffusion can be good alternatives because they are simpler and faster than broth-based methods ${ }^{43,44}$.

The tested compounds (a,1a,2a,3a,4a,5a, equal to $\mathrm{L}_{1}, \mathrm{~L}_{1}-\mathrm{Ce}(\mathrm{III}), \mathrm{L}_{1}-\mathrm{La}(\mathrm{III}), \mathrm{L}_{1}-\mathrm{Sm}(\mathrm{III})$, $\mathrm{L}_{1}-\mathrm{UO}_{2}$ (II) and $\mathrm{L}_{1}-\mathrm{Th}(\mathrm{IV})$ and $\mathrm{b}, 1 \mathrm{~b}, 2 \mathrm{~b}, 3 \mathrm{~b}, 4 \mathrm{~b}, 5 \mathrm{~b}$, equal to $\mathrm{L}_{2}, \mathrm{~L}_{2}-\mathrm{Ce}(\mathrm{III}), \mathrm{L}_{2}-\mathrm{La}(\mathrm{III}), \mathrm{L}_{2}-$ $\mathrm{Sm}(\mathrm{III}), \mathrm{L}_{2}-\mathrm{UO}_{2}$ (II) and $\mathrm{L}_{2}-\mathrm{Th}(\mathrm{IV})$, respectevally were dissolved in DMSO to give a final 
concentration $(1 \mathrm{mg} / \mathrm{mL})$. Susceptible sterile discs were impregnated by the tested substance $(50 \mu \mathrm{g} / \mathrm{disc})$ via a means of micropipette. The biological activity for each substance was tested on surface-seeded nutrient agar medium with the prepared susceptible discs.

\section{Results and Discussion}

Thienopyridazine ligands containing coordinate sites such as ethyl 5-amino-3-(oaminotoluene)-4-oxo-3,4-dihydrothieno[3,4-d]pyridazine -1-carboxylate $\left(\mathrm{L}_{1}\right)$ and ethyl 5amino-3-(4-nitrophenyl)-4-oxo-3,4-dihydrothieno[3,4-d]pyridazine-1-carboxylate $\left(\mathrm{L}_{2}\right)$ are good for chelation with $\mathrm{La}(\mathrm{III}), \mathrm{Ce}(\mathrm{III}), \mathrm{Sm}(\mathrm{III}), \mathrm{Th}(\mathrm{IV})$ and $\mathrm{UO}_{2}$ (II) metals (Scheme 1). Treatment of metals with ligands $\mathrm{L}_{1}$ and $\mathrm{L}_{2}$ in ethanol gave stable six membered ring structure complexes characterized by elemental analysis (Table 1), IR, ${ }^{1} \mathrm{H}$ NMR, Mass spectra.

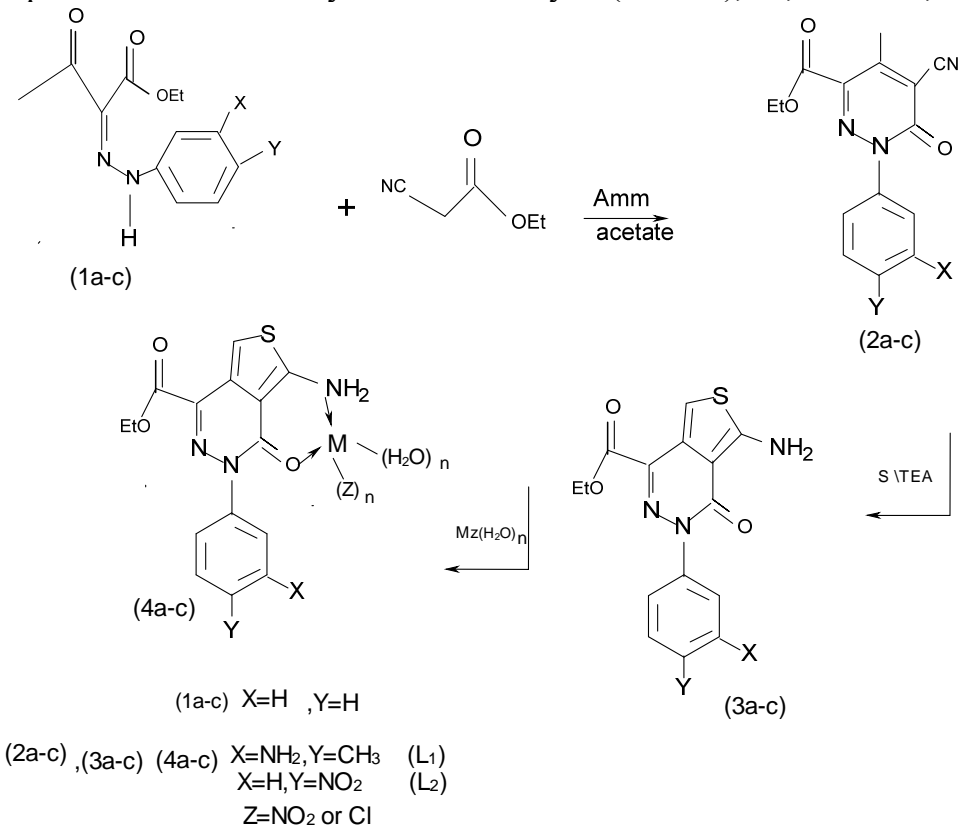

\section{IR spectra}

Scheme 1

The infrared spectral data provide some significant results which support the proposed formula of each complex (Table 2-3) isolated in the present study. The ligand exhibits a broad band at $3431.7 \mathrm{~cm}^{-1}$ and $3377.9 \mathrm{~cm}^{-1}$ for $\mathrm{L}_{1}$ andL $\mathrm{L}_{2}$ due to $v \mathrm{NH}_{2}$ which appears lower shifted in the spectra of its complexes. This indicates that the nitrogen of this group is coordinated to the metal. The band that appears around $1631.5 \mathrm{~cm}^{-1}$ and $1628.6 \mathrm{~cm}^{-1}$ in the spectrum of the free ligands $\mathrm{L}_{1}$ and $\mathrm{L}_{2}$ respectively, probably attributed to $v \mathrm{C}=\mathrm{O}$ ring vibration. The shift in frequency of this band on chelation is probably due to the involvement of $\mathrm{C}=\mathrm{O}$ group in metal chelates ring. A new band appear at 3906, 3848, 3751 and $3676 \mathrm{~cm}^{-1}$ due to presence water molecules in complexes prepared. Since it was known ${ }^{37}$ that the free water absorb at $3520 \mathrm{~cm}^{1}$. One can suggest that water molecules are loosely coordinated or exist as molecules of crystallization. Bands observed at $840,850,876 \mathrm{~cm}^{-1}$ confirm the presence of coordinated lattic water molecules ${ }^{45}$. The hight affinity of $\mathrm{H}_{2} \mathrm{O}$ molecules for heavy metals with its small size and high coordination number of latter ${ }^{46}$, frequently leades to inclusion of $\mathrm{H}_{2} \mathrm{O}$ molecules in coordination sphere of the metal ion. 
Table 2. Fundamental Infrared Bands $\left(\mathrm{cm}^{-1}\right)$ of $\mathrm{L}_{1}$ and its (1:1) Chelates

\begin{tabular}{ccccccc}
\hline \multirow{2}{*}{ Ligand } & \multicolumn{7}{c}{ Complexes Assignments } \\
\cline { 2 - 7 } 3431.7 & 3432.7 & 3392.2 & 3426.9 & 3425.7 & 3408.6 & $v\left(\mathrm{NH}_{2}\right)$ \\
stretching \\
2921.6 & 2923.6 & 2972.7 & 2973.7 & 2923.6 & 2920.6 & $v($ H-aromatic $)$ \\
2360.4 & 2367.2 & 2366.2 & 2364.3 & 2343.1 & 2340.2 & $v\left(\mathrm{CH}_{3}\right)$, \\
1631.5 & 1633.4 & 1629.6 & 1635.3 & 1634.4 & 1634.3 & $v(\mathrm{C}=\mathrm{O})$ \\
- & 875.5 & 876.9 & 876.5 & 834.1 & 809.9 & stretching \\
& 555.4527 .4 & 597.8 & 563.1 & 567.1 & 609.3 & $v(\mathrm{MN})$ \\
- & $450.3,461.9,475.4$ & 457.1 & 438.7 & 420.4 & 425.1 & stretching \\
- & & & & $\mathrm{MO})$ \\
\hline
\end{tabular}

Table 3. Fundamental Infrared Bands $\left(\mathrm{cm}^{-1}\right)$ of $\mathrm{L}_{2}$ and its $(1: 1)$ Chelates

\begin{tabular}{|c|c|c|c|c|c|c|}
\hline \multirow{2}{*}{ Ligand } & \multicolumn{5}{|c|}{ Complexes Assignments } & \\
\hline & $\mathrm{Ce}(\mathrm{III})$ & $\mathrm{La}(\mathrm{III})$ & $\mathrm{Sm}(\mathrm{III})$ & $\mathrm{UO}_{2}(\mathrm{II})$ & Th(IV) & \\
\hline 3477.9 & 3415.3 & 3425.9 & 3426.9 & 3431.7 & 3429.8 & $\begin{array}{c}v\left(\mathrm{NH}_{2}\right) \\
\text { stretching }\end{array}$ \\
\hline 2928.4 & 2923.6 & 2922.6 & 2920.7 & 2930.3 & 2926.5 & $v(\mathrm{H}$-aromatic $)$ \\
\hline 1628.6 & 1652.7 & 1649.8 & 1656.6 & 1651.7 & 1637.3 & $\begin{array}{c}v(\mathrm{C}=\mathrm{O}) \\
\text { stretching }\end{array}$ \\
\hline- & 850.4 & 852.4 & 850.5 & 852.4 & 841.8 & $v(\mathrm{OH})$ \\
\hline- & 580.5 & 528.4 & 692.3 & 580.4 & 533.2 & $\begin{array}{c}v(\mathrm{MN}) \\
\text { stretching }\end{array}$ \\
\hline- & 490.1 & $448.4,433.9$ & 430.9 & 422.3 & 441.6 & $v(\mathrm{MO})$ \\
\hline
\end{tabular}

Further, the ligand does not shows up a band at $748 \mathrm{~cm}^{-1}$ due to $v \mathrm{C}-\mathrm{S}^{47,48}$, which undergoes does not shifted in complexes indicating that sulphur does not involved in complexation $^{49}$. In the IR spectra of the chelate, an additional band is observed which are not found in the spectra of the free ligands. Of these, the bands around 1030,1031,1032 $\mathrm{cm}^{-1}$ observed in the spectra of $\mathrm{UO}_{2}$ (II), Th(IV), Sm(III) complexes respectively, which are assigned to the coordinated $\mathrm{NO}_{3}$ group to metal ion ${ }^{50,51}$. The bands at $1272 \mathrm{~cm}^{-1}$ in the case of $\mathrm{La}$ (III) complexes are due to (M-Cl). The $\mathrm{UO}_{2}(\mathrm{II})$ complexes show strong bands at around 928 and $815 \mathrm{~cm}^{-1}$ assignable to $v_{\mathrm{as}}$ and $v_{\mathrm{sy}}(\mathrm{O}=\mathrm{U}=\mathrm{O})$ modes respectively ${ }^{52}$, this indicates linearity of $\mathrm{O}=\mathrm{U}=\mathrm{O}$ is retained in complexes. Moreover, the two new bands observed in all complexes under study at $530-580 \mathrm{~cm}^{-1}$ and $422-490 \mathrm{~cm}^{-1}$ assigned to vM-N and $v \mathrm{M}-\mathrm{O}$ stretching mode respectively ${ }^{53,54}$.

\section{${ }^{1} H$ NMR Spectra}

The ${ }^{1} \mathrm{H}$ NMR Spectra of the free ligand signal $\mathrm{L}_{1}$ and $\mathrm{L}_{2}$ are appearing at $\delta 6.86$ and $\delta 7.67$ ppm respectively which is attributed to the peak of $\mathrm{NH}_{2}$ protons of pyradizine ring, show little shift downfield in the spectra of the chelates $\delta 6.927-7.005 \mathrm{ppm}$ for $\mathrm{L}_{1}$ and $\delta$ 7.69-7.95 ppm for $\mathrm{L}_{2}$ indicating some sort of deshielding as a result of complexation and confirming that this proton is replaced by metal ion. The hydrated nature of the free ligands and the isolated solid complexes is confirmed by the appearance of signal at $\delta 3.31-3.85 \mathrm{ppm}$ region in the ${ }^{1}$ HNMR spectra of all complexes. The downfield signal demonstrates clearly the 
presence of lattic water molecules, since the uncomplexed $\mathrm{H}_{2} \mathrm{O}$ proton occurs at $\delta 4.33$ $\mathrm{ppm}^{55}$. On the other hand, the proton signal of the coordinated $\mathrm{H}_{2} \mathrm{O}$ molecules must exhibit at $\delta$ 2.88-3.29 $\mathrm{ppm}$. The presence of water molecule is in agreement with the suggested formula based on the elemental analysis and is supported by thermal analysis data. The ${ }^{1} \mathrm{H}$ NMR spectra of the complexes show little downfield shifts in the signal of ring protons due to the deshielding effect of the metal ion ${ }^{56}$. The obtained data are listed in Table 4 .

Table 4. Proton ${ }^{1} \mathrm{H}$ NMR spectral of ligands and complexes in DMSO

\begin{tabular}{ccccc}
\hline Compounds & $\begin{array}{c}\delta \mathrm{H}_{2} \mathrm{O} \\
\text { Lattic water }\end{array}$ & $\begin{array}{c}\delta \mathrm{H}_{2} \mathrm{O} \\
\text { Coordinated water }\end{array}$ & $\delta \mathrm{NH}_{2}$ & $\delta$ (ring protons) \\
\hline $\mathrm{L}_{1}$ & - & - & 6.862 & $7.64-7.670$ \\
$\mathrm{~L}_{1}-(\mathrm{La})^{3+}$ & 3.387 & 3.083 & 6.930 & $7.641-7.679$ \\
$\mathrm{~L}_{1}-\mathrm{Ce}^{3+}$ & 3.394 & 3.253 & 6.927 & $7.65-7.680$ \\
$\mathrm{~L}_{1}-\mathrm{Sm}^{3+}$ & 3.383 & 3.146 & 6.930 & $7.650-7.678$ \\
$\mathrm{~L}_{1}-(\mathrm{Th})^{4+}$ & 3.848 & 3.278 & 6.978 & $7.647-7.785$ \\
$\mathrm{~L}_{1}-\left(\mathrm{UO}_{2}\right)^{2+}$ & 3.344 & 3.136 & 7.005 & $7.642-7.671$ \\
$\mathrm{~L}_{2}$ & - & - & 7.67 & $7.90-8.330$ \\
$\mathrm{~L}_{2}-\left(\mathrm{La}^{3+}\right.$ & 3.887 & 3.297 & 7.948 & $8.295-8.354$ \\
$\mathrm{~L}_{2}-\mathrm{Ce}^{3+}$ & 3.316 & 2.884 & 7.950 & $8.295-8.303$ \\
$\mathrm{~L}_{2}-\mathrm{Sm}^{3+}$ & 3.874 & 3.299 & 7.948 & $8.325-8.352$ \\
$\mathrm{~L}_{2}-\left(-(\mathrm{Th})^{4+}\right.$ & 3.320 & 3.122 & 7.919 & $8.020-8.350$ \\
$\mathrm{~L}_{2}-\left(\mathrm{UO}_{2}\right)^{2+}$ & 3.310 & 2.986 & 7.948 & $8.285-8.315$ \\
\hline
\end{tabular}

\section{Molar conductance}

The ionic nature of the complexes under investigation can be further confirmed by measurement of the molar conductance values of $1 \times 10^{-3} \mathrm{~mol} \mathrm{dm}^{-3}$ solutions of the isolated complexes in DMF at $30^{\circ} \mathrm{C}$. The obtained molar conductance values are listed in table 1 . It is evident from the results that the molar conductance values of mononuclear $[1: 1] \mathrm{L}_{1}$ complexes is in the $6.18-19.06 \mathrm{~S}$. $\mathrm{mol}^{-1} \mathrm{~cm}^{2}$ and $[1: 1] \mathrm{L}_{2}$ complexes is in the range 6.72 16.15 S. $\mathrm{mol}^{-1} \mathrm{~cm}^{2}$, which are commensurate with values characteristic for neutral complexes $^{57}$. This reveals a non-electrolytic nature of the synthesized complexes. These results support the suggested formula of the solid chelates on the bases of elemental analysis. Thus, the ligand acts towards the metals studied as a neutral, bidentate one coordinating through the nitrogen of $\mathrm{NH}_{2}$ group and $\mathrm{C}=\mathrm{O}$ group of pyridazine ring.

\section{Mass spectrum of the ligands}

The mass spectrum of the ligand $\mathrm{L}_{1}$ gives a molecular ion of $\mathrm{M} / \mathrm{e}=344$ of abundance $61.86 \%$. The mass spectrum pattern gives a molecular ion of $\mathrm{M} / \mathrm{e}=255$ which related to the mass of the reminder part of the ligand radical after losing of amino and $\mathrm{EtO}_{2} \mathrm{C}$ groups. This followed by losing $\mathrm{NH}_{2}$ group forming a molecular ion of $\mathrm{M} / \mathrm{e}=239$ of abundance $55.67 \%$. This followed by losing $\mathrm{C}_{6} \mathrm{HN}_{2} \mathrm{OS}$ group forms a molecular ion $\mathrm{C}_{7} \mathrm{H}_{6}{ }^{+}$positive radical $\mathrm{M} / \mathrm{e}=$ 90. The remaining residual fragment of toluene (methyl benzene) positive radical $\mathrm{C}_{7} \mathrm{H}_{6}{ }^{+}$ Forming aresonance stabilized benzylic carbocation, which rearranges to tropylium cation, and this strong peak at $\mathrm{m} / \mathrm{e}=90$ is a hallmark of compounds containing a benzyl unit. The minor peak $\mathrm{C}_{5} \mathrm{H}_{4}{ }^{+} \mathrm{M} / \mathrm{e}=64$ of abundance $100 \%$ represents loss of neutral acetylene from the tropylium ion. On the other hand, the mass spectrum pattern appears fragment of $\mathrm{C}_{7} \mathrm{H}_{6}{ }^{+}$may be loss $\mathrm{CH}_{3}$ group and giving phenyl group positive radical M/e $=75$ of abundance $88.66 \%$, this will appear clearly (Scheme 2 ) as followed. 


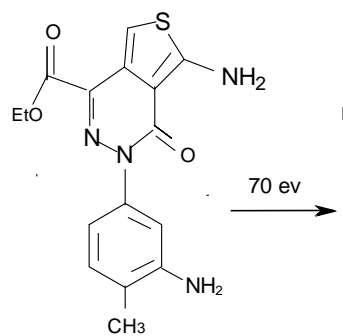

$\mathrm{Mle}=344$

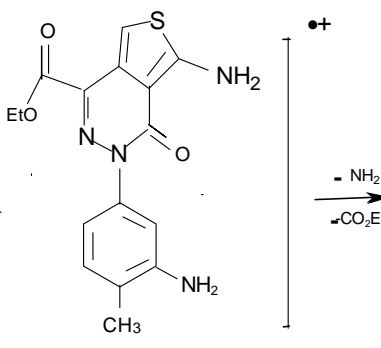

$\mathrm{Me}=344 \quad(61.86 \%)$

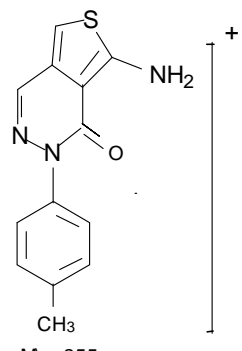

$\mathrm{Me}=255$

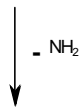

$-\mathrm{NH}_{2}$

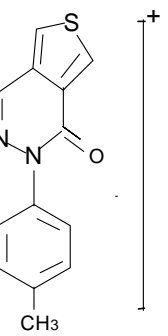

$\mathrm{Mle}=239 \quad(55.67 \%)$

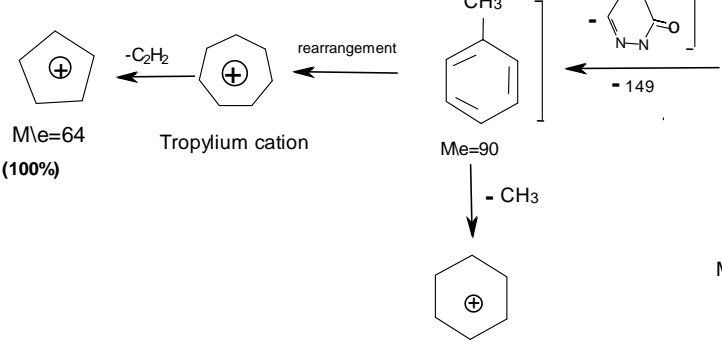

$\mathrm{Mle}=75 \quad$ (88.66\%)

Scheme 2. Mass spectra framentation of $\mathrm{L}_{1}$

The mass spectrum of the ligand $\mathrm{L}_{2}$ gives a molecular ion of $\mathrm{M} / \mathrm{e}=360$ of abundance $82 \%$. The molecular ion of $\mathrm{M} / \mathrm{e}=271$ which related to the mass of the reminder part of the ligand radical after losing of amino and $\mathrm{EtO}_{2} \mathrm{C}$ groups. This followed by losing $\mathrm{C}_{6} \mathrm{HN}_{2} \mathrm{OS}$ group forming a molecular ion of $\mathrm{M} / \mathrm{e}=122$ of abundance $36.34 \%$. The losing of mass of $\mathrm{NO}_{2}$ is followed by forming phenyl radical $\mathrm{M} / \mathrm{e}=76$ of abundance $18.54 \%$ and followed by losing $\mathrm{C}_{2} \mathrm{H}_{2}$ group gave $\mathrm{C}_{4} \mathrm{H}_{2}^{+}$a molecular ion of $\mathrm{M} / \mathrm{e}=50$ of abundance $15.45 \%$.

On the other hand, mass spectrum of the molecular ion of $\mathrm{M} / \mathrm{e}=122$ may be rearrangement and losing NO radical during fragmentation aryloxy is indicated by appearing of peak of $\mathrm{M} / \mathrm{e}=92$ of abundance $38.24 \%$. The lossing of mass of $\mathrm{C} \equiv \mathrm{O}$ group is followed by forming aromatic ring as positive radical $\mathrm{C}_{5} \mathrm{H}_{4}{ }^{+}$a molecular ion of $\mathrm{M} / \mathrm{e}=64$ of abundance $32.92 \%$ The following (Scheme 3) show the above discussion.

\section{Thermal analysis and mass spectra of the complexes}

The TG thermogram of the $(1: 1) \mathrm{La}^{+3}-\mathrm{L}_{1}$ complex shows four thermal degradation stages changes at temperature ranges $27-107,108-280,281-697,-698-1097{ }^{\circ} \mathrm{C}$. In the first stage, occurring at $27-107{ }^{\circ} \mathrm{C}$ the process is accompanied by a weigh loss of $10.88 \%$ corresponding to evalution of four molecules of water of crystallization. In the second step at temperature range $108-280{ }^{\circ} \mathrm{C}$ three molecules of water coordination amine and methyl groups gives mass loss of $11.52 \%$ of abundance $57.41 \%$, forming a molecular ion M/e 558.4. The third steps occurs at temperature ranges $281-697{ }^{\circ} \mathrm{C}$, they may be regarded as aresult of breaking two chloride ion, $\mathrm{C}_{6} \mathrm{H}_{3}{ }^{+}$and $\mathrm{EtO}_{2} \mathrm{C}$ groups by weight loss of $30.97 \%$ forming molecular ion $\mathrm{M} / \mathrm{e}=339.4$ of aboundance $65 \%$. The final step at temperature ranges $698-1097{ }^{\circ} \mathrm{C}$ represents 
mass loss $25.71 \%$ of $\mathrm{N}_{2}$ gas , chloride ion and $\mathrm{C}_{6} \mathrm{H}_{3} \mathrm{NS}^{+}$, so the compound convert into metal oxide $(\mathrm{LaO}) \mathrm{M} / \mathrm{e} 154.9$ of aboundance $\mathrm{M}^{+}=7.04 \%$, where (a) is mass spectra fragmentation and (b)is thermal fragmentation (Scheme 4) .

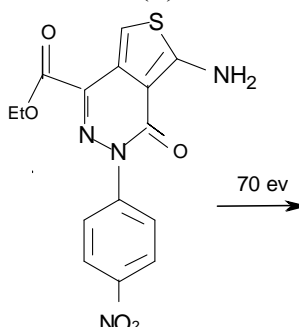

Mle $=360$<smiles>CCOC(=O)c1nn(-c2ccc([N+](=O)[O-])cc2)c(=O)c2c(N)scc12</smiles>

Mle $=360(82 \%)$

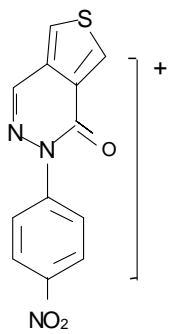

$\mathrm{Mle}=271$
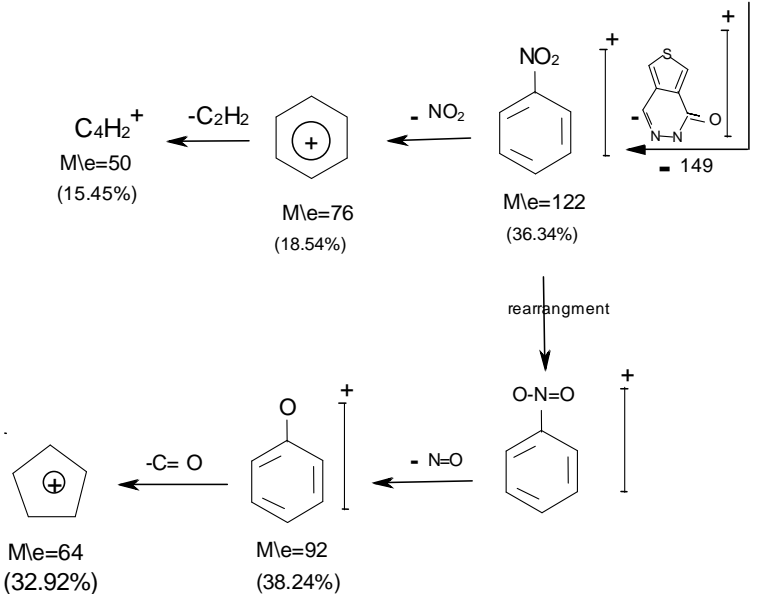

Scheme 3. Mass spectra framentation of $\mathrm{L}_{2}$

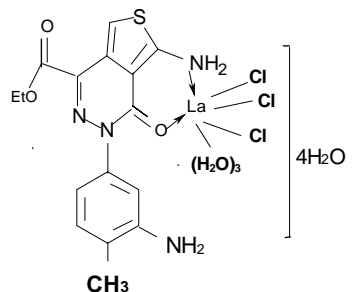

$=715$

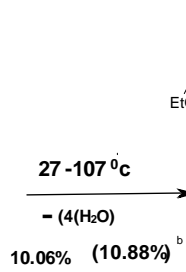

$10.06 \%(10.88 \%)^{b}$

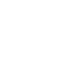

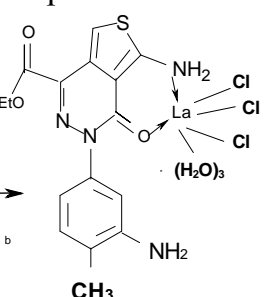

$\mathrm{CH}_{3}$

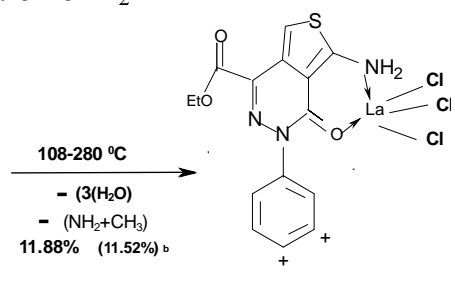

$M e=558.4 \quad(57.41 \%)^{a}$

$\mathrm{Me}=643.4$

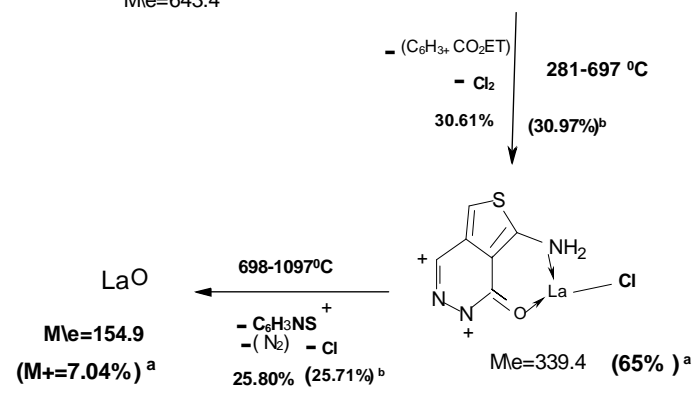

Scheme 4. Themal and mass spectra fragmentation of $\mathrm{L} 1+\mathrm{La}(\mathrm{III})$ chelate 
The TG thermogram of the $(1: 1) \mathrm{UO}_{2}{ }^{+2}-\mathrm{L}_{1}$ complex shows four thermal degradation stages changes at temperature ranges $36-124,125-244,301-645,850-1099{ }^{\circ} \mathrm{C}$. In the first stage lies at 36-124 ${ }^{\circ} \mathrm{C}$ and correspond to loss two molecules of water of crystallization $4.45 \%$. In the second inflection at temperature range $125-244{ }^{\circ} \mathrm{C}$ gives mass loss of $31.41 \%$ corresponds to the breaking of four molecules of water coordination, $\left(\mathrm{NO}_{3}\right)_{2}$ and $\mathrm{EtO}_{2} \mathrm{C}$ molecules ion $\mathrm{M} / \mathrm{e}=541.03$. The third step in TG curve the complex loss $23.36 \%$ form its mass due to the elimination of $\mathrm{N}_{2}$ gas, $\mathrm{C}_{3} \mathrm{HS}^{+}$ , $\mathrm{C}_{7} \mathrm{H}_{8} \mathrm{~N}$ group with in temperature at $301-645^{\circ} \mathrm{C}$, forming molecules ion $\mathrm{M} / \mathrm{e}=338.03(0.3 \%)$. The final step at temperature ranges $850-1099^{\circ} \mathrm{C}$ represent , the loss of residual organic part ion $7.83 \%$ so that the compound converted metal oxide $\mathrm{UO}_{2}^{+2}$ (Scheme 5).

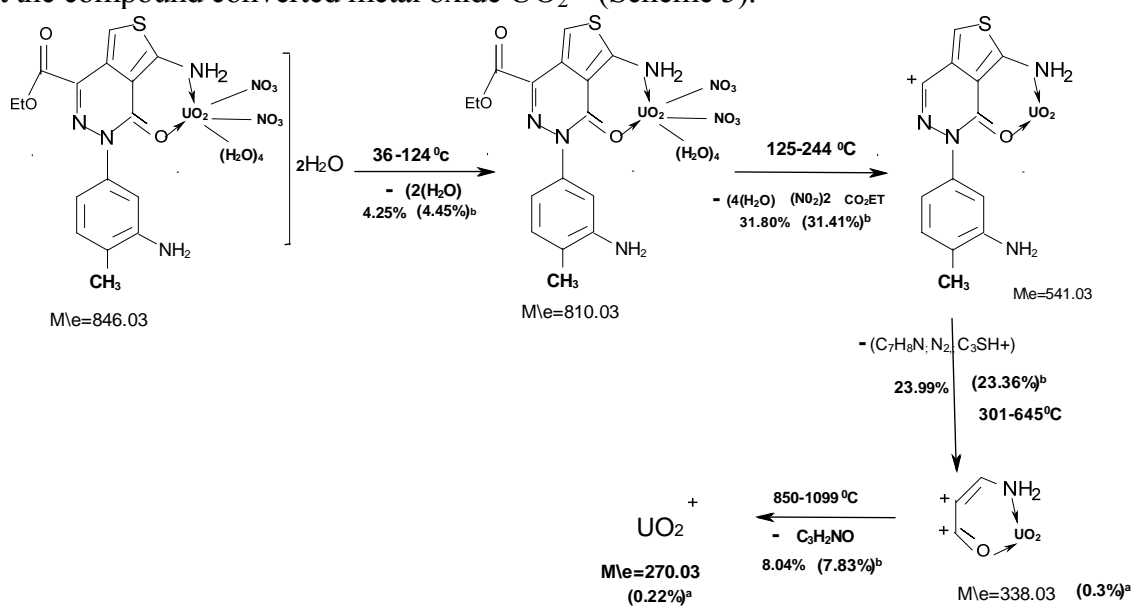

Scheme 5. Thermal of and mass spectra fragmentation of $\mathrm{L} 1+\mathrm{UO}_{2}$ (II) chelate

The TG thermogram of the $(1: 1) \mathrm{Sm}^{3+}-\mathrm{L}_{2}$ complex defines four thermal changes. The first stage at temperature range $34-149{ }^{\circ} \mathrm{C}$ is accompanied by a weight loss of one molecules of water of crystallization $2.66 \%$. In the second step at temperature range 148 $340^{\circ} \mathrm{C}$, this peak represents the start of ligand degradation. The $55.69 \%$ mass loss corresponds to loss five molecules of water of coordination, $\left(\mathrm{NO}_{3}\right)_{2}, \quad \mathrm{EtO}_{2} \mathrm{C}$ and $p$-nitro benzene ,forming molecules ion $\mathrm{M} / \mathrm{e}=315.4$ of abundance $100 \%$. The third inflection at temperature rang $348-646{ }^{\circ} \mathrm{C}$ gives a mass loss of $13.5 \%$ corresponds to the breaking of $\mathrm{N}_{2}$ gas and $\mathrm{C}_{3} \mathrm{H}_{5}{ }^{+}$group forming molecules ion 218.4. The four stage at temperature range $648-999.8^{\circ} \mathrm{C}$ represents, the loss of residual organic part ion $7.03 \%$ so that the compound converted metal oxide $\mathrm{SmO}$ molecules ion $\mathrm{M} / \mathrm{e}=166.4$ of abundance $1.68 \%$ (Scheme 6 ).

The pyrolysis of $(1: 1) \quad \mathrm{UO}_{2}{ }^{+2}-\mathrm{L}_{2}$ complexes shows five inflections in the TG curve. The first stage lies at $36-100{ }^{\circ} \mathrm{C}$ and corresponds to a loss of one molecule of water of crystallization (1.54\%). The second inflection at temperature rang $101-182{ }^{\circ} \mathrm{C}$ gives a mass loss of $10.789 \%$ corresponds to the breaking of two molecules of water coordination and loss of $\mathrm{NO}_{2}$ group forming molecules ion 708.03 of abundance $1.02 \%$. The third inflection at temperature range $182-202{ }^{\circ} \mathrm{C}$, gave mass loss of $33.04 \%$ which corresponds to the breaking of $\left(\mathrm{NO}_{3}\right)_{2}, \mathrm{EtO}_{2} \mathrm{C}$ and $\mathrm{C}_{6} \mathrm{H}_{4}^{+}$groups, forming molecules ion $\mathrm{M} / \mathrm{e}=435.03$ of abundance $1.19 \%$. The weight loss of $11.896 \%$ corresponds to the loss of $\mathrm{N}_{2}$ gas and $\mathrm{C}_{3} \mathrm{HS}^{+}$group occurs at temperature range $520-718{ }^{\circ} \mathrm{C}$ in $\mathrm{TG}$ curve, forming a molecular ion $\mathrm{M} / \mathrm{e} 338.03$ of abundance $1.23 \%$. In the final process at temperature range $818-953{ }^{\circ} \mathrm{C}$, which due to loss of the remain part of $\mathrm{C}_{3} \mathrm{H}_{2} \mathrm{NO}$ with a mass of $7.84 \%$ then the complex converted metal oxide $\mathrm{UO}_{2}{ }^{+2}$ as an end product (Scheme 7). 


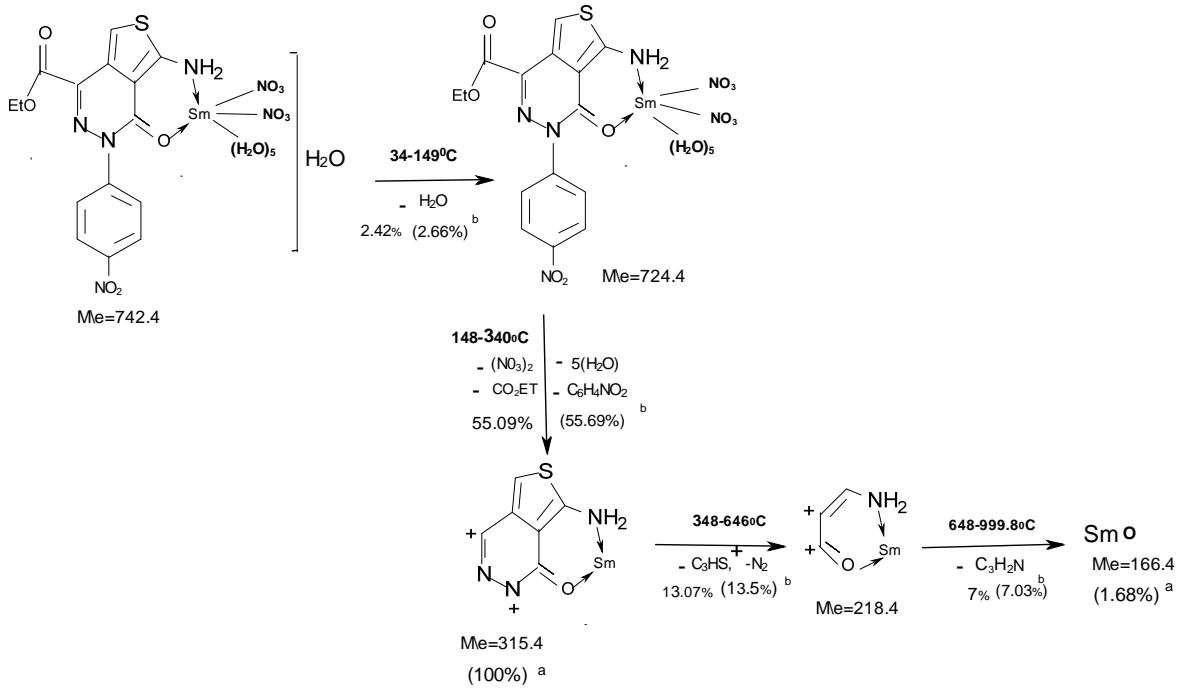

Scheme 6. Thermal and mass spectra fragmentation of $\mathrm{L}_{2}+\mathrm{Sm}(\mathrm{III})$ chelate<smiles></smiles>

$\mathrm{Mle}=\mathbf{8 0 8 . 0 3}$

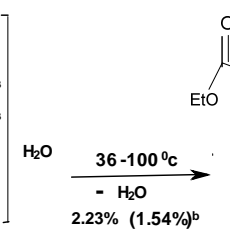

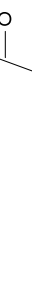

Mle $=790.03$

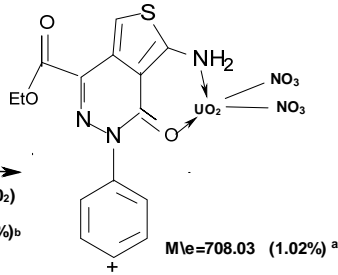

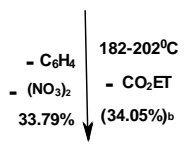
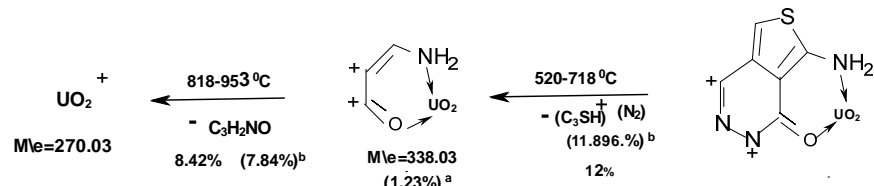

Mle $=435.03 \quad(1.19 \%)$ a

Scheme 7. Thermal and mass spectra fragmentation of $\mathrm{L} 2+\mathrm{UO}_{2}(\mathrm{II})$ chelate Antimicrobial activity

Structure-antimicrobial (biological) activity relation-ship for some selected newly synthesized dihydrothieno[3,4,D]pyridazine compounds a,1a,2a,3a,4a,5a, equal to $\mathrm{L}_{1}, \mathrm{~L}_{1}$ $\mathrm{Ce}(\mathrm{III}), \mathrm{L}_{1}-\mathrm{La}(\mathrm{III}), \mathrm{L}_{1}-\mathrm{Sm}(\mathrm{III}), \mathrm{L}_{1}-\mathrm{UO}_{2}$ (II) and $\mathrm{L}_{1}-\mathrm{Th}(\mathrm{IV})$ and $b, 1 b, 2 b, 3 b, 4 b, 5 b$, equal to $\mathrm{L}_{2}$, $\mathrm{L}_{2}-\mathrm{Ce}(\mathrm{III}), \mathrm{L}_{2}-\mathrm{La}(\mathrm{III}), \mathrm{L}_{2}-\mathrm{Sm}(\mathrm{III}), \mathrm{L}_{2}-\mathrm{UO}_{2}$ (II) and $\mathrm{L}_{2}-\mathrm{Th}(\mathrm{IV})$, respectevally were studied and determined against some bacterial Escherichia Coli (Gram-negative bacteria), Staphylococcus Aureus (Gram-positive bacteria), and fungi strains Candida, Ampicillim was used as the standard antibacterial agent and Amphotericin was used as the standard Antifungal agent. The antibacterial activity showed that all compounds were active against microorganisms. All compounds were less active in comparison to Ampicillim, which was taken as a standard drug. Further, investigation on the biological activity of these compounds will be considered in the progress. Inactive fungi strains (inhibition zone $<9.3 \mathrm{~mm}$ ). 
The data obtained are expressed as size $(\mathrm{mm})$ of inhibition zone. Diameter of the inhibition zones were high (22-18 mm), moderate (17-12 mm), slight (11-1 mm), no response (-).It is clear from the microbiocidal screening data that the metal complexes are more toxic in comparison to their parent ligand itself. Hence complexation increase the antimicrobial activity ${ }^{58}$, such increased activity of the metal complexes can also be explained on the bass of chelation theory ${ }^{59,60}$. Bacterial and fungus strains and the biological effect are shown in Table 5.

Table 5. Biological activity of some new synthesized complexes

\begin{tabular}{|c|c|c|c|c|}
\hline \multirow[b]{2}{*}{ Sample } & \multicolumn{4}{|c|}{ Inhibition Zone diameter (mm/mg sample) } \\
\hline & $\begin{array}{l}\text { Escherichia } \\
\text { Coli }\left(\mathrm{G}^{-}\right)\end{array}$ & $\begin{array}{l}\text { Staphylococcus } \\
\text { Aureus }\left(\mathrm{G}^{+}\right)\end{array}$ & $\begin{array}{l}\text { Candida } \\
\text { Albicans } \\
\text { (Fungus) } \\
\end{array}$ & $\begin{array}{l}\text { Aspergillus } \\
\text { Flavus } \\
\text { (Fungus) } \\
\end{array}$ \\
\hline Control: DMSO & 0 & 0 & 0 & 0 \\
\hline Ampicillin & 22 & 18 & & \\
\hline $\begin{array}{l}\text { Antibacterial Agent } \\
\text { Amphotericin B } \\
\text { Antifungal Agent }\end{array}$ & - & - & 19 & 16 \\
\hline $\mathrm{a}$ & 10 & 10 & $12 \mathrm{R}$ & 0 \\
\hline $1 \mathrm{a}$ & 11 & 10 & 9 & 0 \\
\hline $2 a$ & 13 & 12 & 9 & 0 \\
\hline $3 a$ & 12 & 11 & 0 & 0 \\
\hline $4 a$ & 20 & 18 & 9 & 0 \\
\hline $5 \mathrm{a}$ & 11 & $16 \mathrm{R}$ & 0 & 0 \\
\hline $\mathrm{b}$ & 0 & 0 & 0 & 0 \\
\hline $1 b$ & 11 & 11 & 0 & 0 \\
\hline $2 b$ & 10 & 10 & 9 & 0 \\
\hline $3 b$ & 9 & 0 & 9 & 0 \\
\hline $4 b$ & $16 \mathrm{R}$ & $16 \mathrm{R}$ & 10 & 0 \\
\hline $5 b$ & 11 & 11 & 10 & 0 \\
\hline
\end{tabular}

The final conclusion from this work is that these novel compounds showed significant antibacterial activity according to the following factors:

(1) Diameter of the inhibition zones were high in actinide complexes than lanthanide complexes

(2) The presence of either electron donating and/or accepting group.

\section{Conclusion}

Coordination compound formed by the interaction of dihydrothieno[3,4-d]pyridazine with $\mathrm{La}(\mathrm{III}), \mathrm{Ce}(\mathrm{III}), \mathrm{Sm}(\mathrm{III}), \mathrm{Th}(\mathrm{IV})$ and $\mathrm{UO}_{2}(\mathrm{II})$ are prepared and characterized by elemental analysis, IR, ${ }^{1} \mathrm{HNMR}$ Mass spectra and thermal analysis. The analysis data indicate that the ligand acts as bidentate on chelation, thermogravimetric analysis confirm the presence of coordinates water. The IR spectra indicate that coordination takes place through the nitrogen of amino group and $\mathrm{C}=\mathrm{O}$ group of pyridazine ring. Antimicrobial activity of selected compounds against some bacterial strains was tested and confirm the antimicrobial activities of the ligand increase on coordination with the metal ion.

\section{Acknowledgement}

The author thankful to the Department of Chemistry, Aswan Faculty of Science, Aswan University, Aswan, Egypt for support of the work. 


\section{References}

1. Asif M, Curr Med Chem., 2012, 19(18), 2984-2991; DOI;10.2174/092986712800672139

2. Siddiqui A, Mishra R, Husain A, Rashid M and Pal P, Bioorg Med Chem Lett., 2011, 21(3), 1023-1026; DOI:10.1016/j.bmcl.2010.12.028

3. Rathish I, Kalim J, Shamim A, Sameena B, Alam M, Akhter M, Pillai K, Ovais S and Samim M, Eur J Med Chem., 2012, 49, 304-309; DOI:10.1016/j.ejmech.2012.01.026

4. Othman M M, Nasr H M and Hassan M I, Can Chem T., 2014, 2, 504- 517; DOI:10.13179/canchemtrans.2014.02.04.0133

5. Ruso J, Rajendiran N, Srinivas C, murthy KN and Soumya K, J Kor Chem Soc., 2014, 58(4), 377-380; DOI:10.5012/jkcs.2014.58.4.377

6. Attanasi O A, Favi G, Filippone P, Perrulli F R and Santeusanio S, Org Lett., 2009, 11(2), 309-312; DOI:10.1021/o1802432z

7. Wang X J, Du G J, Zhao S Q, Yan M and Gu L Q, Chem Biol Drug Des., 2009, 74(3), 276-281; DOI:10.1111/j.1747-0285.2009.00859.x

8. Tucker J, Allwine D, Grega K, Barbachyn M, Klock J, Adamski J, Brickner S, Hutchinson D, Ford C, Zurenko G, Conradi R, Burton P and Jensen R, J Med Chem., 1998, 41(19), 3727-3735; DOI:10.1021/jm9802741

9. Orazio A, Gianfranco F, Paolino F and Francesca R, Org Lett., 2009, 11(2), 309-312; DOI:10.1021/o1802432z

10. Asif M, Singh A and Siddiqui A, Med Chem Res., 2012, 21, 3336-3346; DOI:10.1007/s00044- 011-9835-6

11. Adel M and Maisa E, J Chin Chem Soc Taip., 2002, 49, 1057-1060; DOI:10.1002jecs200200152

12. Rosowsky A, Chaykovsky M, Chen K, Lin M and Modest E J, J Med Chem., 1973, 16(3), 185-188; DOI:10.1021/jm00261a002

13. Shetty N S, Lamani R S and Khazi I M, J Chem Sci., 2009, 121, 301-307; DOI:10.1107/S1600536811021155

14. Onal Z, Zeng H and Sonmez M, Turk J Chem., 2011, 35, 905-914; DOI:10.3906/kim1103-55

15. El-Ansary A, Kamal A and Al-Ghorafi M, Med Chem Res., 2013, 22, 2589-2601; DOI:10.1007/s00044-012-0258.9

16. Saleh A B and Atef M A and Ahmed A F, J Am Sci., 2010, 6, 151-159; DOI:10.7537/j.issn.1545-1003

17. Khaled A, Nadia A, Eman M, Hekmat A and Moustafa E, Med Chem Res., 2010, 19(7), 629- 642; DOI:10.1007/s00044-009-9218-4

18. Bakhite E A, Abdel-Rahman A E, Mohamed O S and Thabet E A, Bull Kor Chem Soc., 2002,23, 1709-1714; DOI:10.5012/bkcs.2002.23.12.1709

19. Voronina A, Litova N, Kuzmin I, Razumov M, Vashurin A, Shepelev M and Pukhovskaya S, Eur Chem Bull., 2014, 3, 857-859; DOI:10.1142/S1088424614501028

20. Srivastava P, Upreti D K, Dhole T N, Srivastava A K and Nayak M T, Perspect Infect Dis., 2013, 2013, 709348-709353; DOI:10.1155/2013/709348

21. Khalil K D and Al-Matar H M, Molecules, 2013, 18, 5288-5305; DOI:10.3390/molecules18055288

22. Elassar A A, Alsughayer A, Sagheer F, J Chem Soc Res., 2013, 37, 191- 255; DOI:10.3184/174751913X13640546938841 
23. Raja N and Ramesh R, Tetrahedron Lett., 2012, 53, 4770-4774; DOI:10.1016/j.tetlet.2012.06.119

24. Tuccinardi T, Zizzari A T, Brullo C, Daniele S, Musumeci F, Schenone S, Trincavelli M, Martini C, Martinelli A, Giorgi G and Botta M, Org Biomol Chem., 2011, 9, 4448-4455; DOI:10.1039/C0OB01064B

25. Grünwald K, Saischek G, Volpe M, Belaj F and Mösch-Zanetti N C, Eur J Inorg Chem ., 2010, 2010, 2297- 2305; DOI:10.1002/ejic.201000120

26. Suárez V , Gutiérrez A, Quintela J M , Peinador C, Quintela J M, J Org Chem., 2009, 74, 6577-6583; DOI:10.1021/jo901034c

27. Ferguson G N, Valant C, Horne J, Figler H, Flynn B L, Linden J, Chalmers D K, Sexton P M, Christopoulos A and Scammells P J, J Med Chem., 2008, 51, 61656172; DOI:10.1021/jm800557d

28. Nara S, Martinez J, Wermuth C, Parrot I, Synlett., 2006, 19, 3185-3204; DOI:10.1055/s-2006-951528; Art ID: A41806ST

29. Fang-Qian L Q, Acta Phys Chim Sin., 2005, 21, 52-56; DOI:10.3866/PKU.WHXB20050111

30. Krajsovszky A, Haider N, Matyus P, Heterocycles, 2001, 55, 1105-1111; DOI:10.3906/kim-210-22

31. Haider N and Käferböck J, Heterocycles, 2000, 53, 2527-2534; DOI:10.3998/ark.555-0190.0009.703

32. Carlucci L, Ciani G, Proserpio D M, and Sironi A, Inorg Chem., 1998, 37, 59415943; DOI:10.1107/S2052252514015966

33. Ghedini M, Neve F, Lanfredi A M ,Ugozzoli F, Inorg Chim Acta., 1988, 147, 243 250; DOI:10.1039/b923729a

34. Ramadan A A, Seada M H, Rizkalla E N, Talanta., 1983, 30, 245-250; DOI:10.11648/j.mc.s.2015030101.13

35. Arvid H and Skancke P N, Acta Chem Scand., 1972, 26, 2601-2613; DOI:10.891/.Acta.Chem.Scand, 26-2601

36. Yang F, Li X, Wang H, Ni S and Shi D, Acta Cryst., 2006, 62, o3566-o3567; DOI:10.1107/S1600536806028467

37. Ballatore C, Crowe A, Piscitelli F, James M, Bioorg Med Chem., 2012, 20, 44514461; DOI:10.1016/j.bmc.2012.05.027

38. King P, Lomovskaya O, Griffith D, Burns J and Dudley M, Antimicrob Agents Ch ., 2010, 54, 143-148; DOI:10.1128/AAC.00248-09

39. Kuzucu C, Rapino B, McDermott L, and Hadley S, J Clin Microbiol., 2004, 42, 1224-1227; DOI:10.1128/JCM.42.3.1224-1227.2004

40. El-Mashad N, Foad M F, Saudy N, Salem D A, Braz J Microbiol., 2012, 43, 266273; DOI:10.1590/S1517-83822012000100031

41. Varaldo P E and Facinelli B, J Antimicrob Chemother., 2006, 50, 4229-4230. DOI:10.1128/AAC.00943-06

42. Mohamed M A, Ibrahim O B, J Mol Struct., 2014, 1056, 13-24. DOI:10.1016/j.mol-struc.2013.10.019

43. El-Sherif A A, Shehata M R, Shoukry M M and Barakat M H, Spectrochim Acta A, 2012, 96, 889- 897; DOI:10.1016/j.saa.2012.07.047

44. Ganguli K K, Carlisle G O, Hu H J, Theriot L J, Bernal I, J Inorg Nucl Chem., 1971, 33, 3579- 3581; DOI:10.1016/0022-1902(71)80683-8

45. Mondal S, Prasad S, Dutta S and Chakravorty A, J Chem Soc Dalton Trans., 1996, 1, 99-103; DOI:10.1039/DT9960000001

46. Wilkinson G, Gillard R D and McCleverty J A (eds), Comprehensive Coordination Chemistry, 1st edition, Pergamon, Oxford, 1987, 6,541; DOI:10.5402/2011/16859 
47. Gupta H K and Dikshit S K, Transit Metal Chem., 1985, 10, 469-472. DOI:10.1007/BF00620712.

48. Al-Mous S, A. Elassara A and El-Apaserya M, Phosphorus Sulfur Silicon and the Related Elements, 2006, 181, 1755- 1771; DOI:10.1080/10426500500536457

49. Agarwal S K, Saxena A K, Anand N, Synthesis, 1981, 6, 465-466; DOI:10.1055/s1981-29487

50. Stefan S L, J Therm. Anal., 1994, 42, 1299-1312; DOI: 10.1016/j.saa.(2005)06.031

51. Bhattacharjee M,Gogoi P, Barman P, Kalita R, Sarma B, Karmakadoi S, Polyhedron., 2013, 60, 47-53. DOI:10.1016/j.poly.2013.04.062

52. Thoonen S H, Deelman B, Koten G, J Organomet Chem., 2004, 689, 2145- 2157; DOI:10.1016/j.jorganchem(2004).03.027

53. Amin A S , Mohammed T Y ,Talanta., 2001,30, 611-620; DOI:10.1172/JCI35337

54. Kumar S, Leavell S, Porter K, Assogba B and Burkhard M, Retrovirology., 2010,7, 49; DOI:10.1186/1742-4690-7-49

55. Uzoukwu B, Spectrochim Acta A., 1995, 51, 1081-1082; DOI:10.1016/05848539(94)01297-T

56. Abeed A A, J Heterocyclic Chem., 2015,5, 1175-1178; DOI:10.1002/jhet.2225

57. Ong D T, Ballerin G, Morgan L, Buddle L, Scalia S and Young P, AAPS J, 2014,16, 269-280; DOI:10.1208/s12248-014-9560-4

58. Ibrahi D M and Abdel-Latif S A, IOSR-JAC., 2013, 5, 40-50; DOI:10.9790/48610325660

59. Leonor L, Juan M, María S, Oscar F, Eduardo E, Liliana B , Evelina G, Patricia A, J Coord Chem., 2011, 64, 350-356; DOI:10.1016/j.jscs.2011.11.020

60. Abdou S, Fathey A and Ahmed N, J Coord Chem., 2008, 61, 2380- 2401; DOI:10.1080/00958970801914041 